uniformity in growth and morphology of red pine throughout its geographic range. It is a genetically homogeneous and a highly self fertile species, and only once has an interspecific hybrid progeny been produced (Pinus nigra $x$ resinosa at Placerville, California), in spite of repeated attempts to do so at a number of locations.

The panelists agreed that the physiological (growth) variation found in red pine can only be related very broadly to variable factors of the environment of origin and that careful and intensive sampling of specific populations is required to determine the true nature and degree of variation in the species. Some argued that the small practical gains to be expected hardly justified spending much effort on breeding with this species, especially in view of its normally good form and growth when not planted off-site. Others claimed that there is sufficient evidence to warrant intensive studies to find the most productive lines, and that a continuing effort to induce variation through provenance and interspecific hybridization is of potential value for breeding for increased productivity in general and for resistance to introduced insect pests and pathogens in particular.

The two half-day field trips included inspections of hard pine, spruce and larch single tree progeny tests, provenance experiments, hybrid tests, clone tests and grafted breeding orchards. The numerous plantings illustrated the value of the experimental approach in leading to a greater understanding of inherent differences within and between populations and species of trees. Some examples of the difficulties encountered in field experiments were seen, where plot differences were confounded with variations due to differences in soil and/or micro-site (incidence of frost) that are of major importance.

The next meeting of the Committee on Forest Tree Breeding in Canada will be held in cooperation with the Western Forest Genetics Association at the University of British Columbia, Vancouver, B.C. in August 1966. Enquiries concerning attendance at this meeting will be welcomed by the secretary, or the Chairman 1965-66, Dr. O. Sziklai, Faculty of Forestry, University of British Columbia.

C. W. Yeatman

SECRETARY

\title{
Rumania And The Eighth Congress Of The International Society
} OF SOIL SCIENCE, 1964

About 1,200 scientists from 65 countries attended the Eighth Congress of the International Society of Soil Science in Bucharest, Rumania August 31 to September 9, 1964. The purpose of the meeting was to review recent progress in soil science in seven different commissions, namely soil physics, chemistry, biology, fertility and plant nutrition, genesis-classification-cartography, technology, and mineralogy. In all, about four hundred papers were offered in the commissions and several general lectures were given by leading research workers. In addition, work sessions were organized during some evenings; the West European Working Group for Soil Structure is an example. Dozens of forest soil and site research workers were present and the Congress served as a very satisfactory forum for the exchange of research philosophy, methods, results, and goals. Special meetings and field trips were programmed for forestry. 
Field Excursion in North Eastern Rumania

One of the three pre-Congress tours was made in two new Italian Fiat tourist buses and led from Bucharest northeast across the vast Danube Plain to Galati on the Danube River, then north over the Moldavian Tableland to Iasi on the Russian frontier. In turn, Suceava and the wooded northern Carpathian Mountains were seen and the tour returned to Bucharest via forest localities in the eastern Carpathians, Brasov in the Intermountain Depression, and the heavily wooded Prahova Valley.

The tour was aimed at the discussion of thirty-six soil profiles along the route together with a review of the land management practices and local industry. Enroute, several industrial centres were visited, one being the Chiscani Pulp and Paper Mill near Galati where 1,000 employees produce 150 tons of pulp per day from reeds harvested on the Danube Delta.

From a forestry standpoint, about 27 per cent of the country is wooded and almost all forests are in mountains and hilly regions. Beech is the main species; spruce and fir are the chief conifers. Because of the ravages of World War II and the population density (about 18 million people in an area the size of Oregon) fast growing species of spruce, fir, larch, pine and poplar are being planted over large areas and intensive silvicultural practice is justified. Watershed management is high-lighted in the forestry program and dozens of poplar and conifer plantations, control dams and streambed projects were seen.

Even though Rumania is a small country, its geology, soils and climate are complicated. As a result the forests are rich in variety. In the Danube Plain where alluvial and loess (wind deposited silty soils) predominate, oak (Quercus pedunculiflora, $Q$. petraea) and elm (Ulmus campestris) forests are seen; they are small in area as the Plain is now committed mainly to agriculture. Clayey alluvial soils on the Plain support mixed stands of ash (Fraxinus holotricha, $F$. paleca, $F$. excelsior), dogwood (Cornus sanguinea) and elm (ulmus foliacea).

Grey-brown podsolic soils in residual clays on the Moldavian Table-land support oak (Quercus petraea), beech (Fagus sylvatica), and linden (Tilia tomentosa). Further west at the edge of the Carpathian foothills a mixed forest of beech ( $F$. sylvatica), hornbeam (Carpinus betulus), linden (Tilia sp.) and oak ( $Q$. petraea) grows on gleyed podsolic soils on clay loam parent materials. In the higher elevations of the eastern Carpathians (ca. 3,000 feet) mixtures of fir (Abies alba), beech (Fagus sylvatica), maple (Acer pseudoplatanus), and pine (Pinus sylvestris) and Spruce (Picea abies) are extensive. In the high mountain passes south of Brasov magnificent mixed stands of (Fagus sylvatica), spruce (Picea excelsa), and fir (Abies pectinata) grow on rich residual soils (sandstones and marls). Dominant heights of 160 feet and diameters of 3 feet are common. Over large areas of acid brown soils spruce ( $P$. excelsa) plantations have been established.

\section{The Congress}

The Bucharest Meetings were opened by Mr. Gheorghe Gheorghiu-Dej, President of the State Council of the Rumanian People's Republic and scientific sessions formed the remainder of the program. An FAO/UNESCO project on a world map of soils was the subject of a general session as was M. B. Russell's (U.S.A.) "The Dynamics of water in soils and plants" and I. P. 
Gerassimov's (U.S.S.R.) "The modern Dokuchaev Approach to Soil Classification and its Applictaion to Soils Maps in the U.S.S.R. and World". Automation in soils taxonomy was suggested by Mr. O. W. Bidwell's (U.S.A.) paper on "Numerical Classification of Soils by Electronic Computer".

An afternoon meeting of forest soils and site men from Norway, Sweden, East and West Germany, U.S.A., Canada, Russia, Rumania and England heard illustrated talks on "Forest Soil Fertility and Methods for its Improvement" by H. Zöttl (West Germany), F. Hoffman (East Germany) and R. F. Tarrant (U.S.A.). In addition forest site and ecology subjects were given by T. Troedsson (Sweden), W. H. Carmean (U.S.A.), Lag (Norway), M. Jurdant, and P. Duffy of Quebec and Alberta, Canada respectively. The variety of subjects revealed the diversity of problems which confront forest managers. Several European countries look upon fertilization of forest soils under plantations as economic and compatible with the value of forest products grown on the improved soils. The Norwegian forest soil survey is of importance as a basis for forest management planning. Site factor - stand growth studies for site classification as described by Carmean and by Duffy were of interest to the European workers. However, there was no indication of similar studies being conducted in Europe. Use of computers for forestry is only beginning in middle and eastern Europe although the Scandinavian countries and other west European nations have several years of experience.

Proceedings of the Congress will be published in 1965 by the ISSS (address: 65 Mauritskade, Amsterdam, Netherlands).

\section{A Tourist's Impressions}

Three weeks of travel and conferences in Rumania left the impression that the country has a staggering potential, with rich farmland, productive forests, considerable hydro-electric potential, oil and gas (oil production is second in Europe; gas production is fourth in the world), and mineral deposits as well as tidewater ports, a developing tourist industry and a large working force.

One is immediately impressed with the good natured Rumanian manner and the warm hospitality everywhere. Even though Rumania is for the hardened traveller, (the attractions to the Canadian tourist are mainly the features that result from 20 years of Communist government), it is a country of great beauty and contrasts. The surf on the beaches of the Black Sea, wildlife of the Danube Delta, the spreading steppe lands and foothills, and the Carpathian mountains offer a memorable spectrum of impressions. Coupled with Rumanian hospitality, such impressions are not soon forgotten.

The Congress was a considerable success and the Organizing Committee, under Drs. Giosan and Cernescu, deserves high praise for its diligence and hospitality.

P. J. B. DUFFY

For The SARe Of ARgument

Did You Like The New Supplement?

"However, in the final analysis what goes between the covers is up to you. To a very substantial degree our profession is judged at home and abroad by what we publish". (Report of the Editor, 56th Annual Report of the C.I.F.) 